\title{
KORELASI DINAMIS ANTARA PERGERAKAN HARGA MINYAK DUNIA DAN INDEKS HARGA SAHAM SEKTORAL DI BURSA EFEK INDONESIA
}

\author{
Yunita Dewi Safitri*, Robiyanto Robiyanto \\ Universitas Kristen Satya Wacana, Indonesia
}

\begin{abstract}
Changes in the situation that move very quickly on the commodity market have an impact on financial markets, one of which is the stock market in Indonesia. Therefore this study aims to examine the dynamic correlation between the movement of world oil prices and the Sectoral Stock Price Index listed on the Indonesia Stock Exchange (IDX). The data used is obtained from secondary data in the form of daily closing price data for world oil prices and Sectoral Stock Price Index from January 2017 to June 2020. The analysis technique used is Dynamic Conditional Correlation-Generalized Autoregressive Conditional Heteroscedasticity (DCC-GARCH), due to previous studies mostly using a static approach. The results of this study show that the DCCGARCH value between world oil prices (Brent and WTI) and Sectoral Stock Price Index tends to be very weak. A negative dynamic correlation was also found in the Consumer Goods Sector. This research can be a reference for investors who want to invest stocks in Indonesia by looking at the correlation between world oil prices and the Sectoral Stock Price Index.
\end{abstract}

JEL : G10, G15, Q41

Keywords : Europe Brent, West Texas Intermediate (WTI), Dynamic Conditional CorrelationGeneralized Autoregressive Conditional Heteroscedasticity (DCC-GARCH), Sectoral Stock Price Index

\begin{abstract}
ABSTRAK
Perubahan situasi yang bergerak sangat cepat pada pasar komoditas memberi dampak pada pasar finansial salah satunya pasar saham di Indonesia. Oleh karena itu penelitian ini bertujuan untuk mengkaji korelasi dinamis antara pergerakan harga minyak dunia dan Indeks Harga Saham Sektoral yang terdaftar di Bursa Efek Indonesia (BEI). Data yang digunakan merupakan data sekunder berupa data harga penutupan harian harga minyak dunia dan Indeks Harga Saham Sektoral dari periode Januari 2017 hingga Juni 2020. Teknik analisis yang digunakan adalah Dynamic Conditional Correlation-Generalized Autoregressive Conditional Heteroscedasticity (DCCGARCH), dikarenakan penelitian-penelitian sebelumnya sebagian besar menggunakan pendekatan statis. Hasil penelitian ini menunjukkan bahwa nilai DCC-GARCH antara harga minyak dunia (Brent dan WTI) dengan Indeks Harga Saham Sektoral cenderung sangatlah lemah. Ditemukan juga korelasi dinamis negatif pada Sektor Saham Barang Konsumsi. Penelitian ini dapat menjadi referensi bagi investor yang ingin melakukan investasi saham di Indonesia dengan melihat korelasi antara harga minyak dunia dan Indeks Harga Saham Sektoral.
\end{abstract}

Kata Kunci : $\quad$ Europe Brent, West Texas Intermediate (WTI), Dynamic Conditional CorrelationGeneralized Autoregressive Conditional Heteroscedasticity (DCC-GARCH), Indeks Harga Saham Sektoral

\section{PENDAHULUAN}

Pada hakikatnya investasi merupakan suatu aktivitas penanaman dana atau modal yang dimiliki oleh seseorang, baik secara langsung maupun tidak langsung dengan harapan pemilik modal mendapat hasil dari manfaat investasi mereka dikemudian hari. Investasi dalam pasar modal adalah salah satu jenis investasi yang menguntungkan. Namun saat ini tidak hanya pasar keuangan yang mendominasi investasi tetapi telah merambah ke pasar komoditas. Menurut Hersugondo, Robiyanto, Wahyudi, \& Muharam (2015) pasar komoditas semakin berkembang

${ }^{*}$ Email : 212017212@student.uksw.edu

Received : 29-10-2020, Accepted : 23-12-2020, Published : 28-12-2020

P-ISSN : 2087-9954, E-ISSN : 2550-0066. DOI : http://dx.doi.org/10.26418/jebik.v9vi3.42949 
menyebabkan pergerakan harga di pasar komoditas sehingga mampu mempengaruhi pergerakan harga saham di pasar saham. Menurut Lin, Wesseh, \& Appiah (2013) komoditas yang paling penting di pasar keuangan global adalah minyak, sehingga ketika pasar minyak dunia dan pasar keuangan berada pada periode yang sama dengan volatilitas tinggi, sangat mungkin untuk menciptakan transmisi kejutan antara dua pasar tersebut.

Klein (2018) berpendapat bahwa ada dua harga minyak mentah yang digunakan sebagai patokan oleh internasional yaitu Europe Brent dan West Texas Intermediate (WTI). Tidak dapat dipungkiri sebagai sumber input utama di dunia tingkat ketergantungan terhadap minyak mentah terus meningkat. Ratti \& Vespignani (2015) serta Souček (2013) menyatakan bahwa minyak dipandang sebagai faktor utama dalam menentukan indeks harga saham dunia. Tursoy \& Faisal (2018) mengatakan harga komoditas khususnya minyak memiliki peran penting dan berdampak pada pasar saham di Turki. Di Indonesia pergerakan indeks harga saham sangat fluktuatif. Salah satu aspek yang berpengaruh terhadap pergerakan indeks harga saham gabungan adalah adanya perubahan harga minyak dunia. Pada Gambar 1. dapat dilihat mengenai pergerakan antara harga minyak dunia serta IHSG.

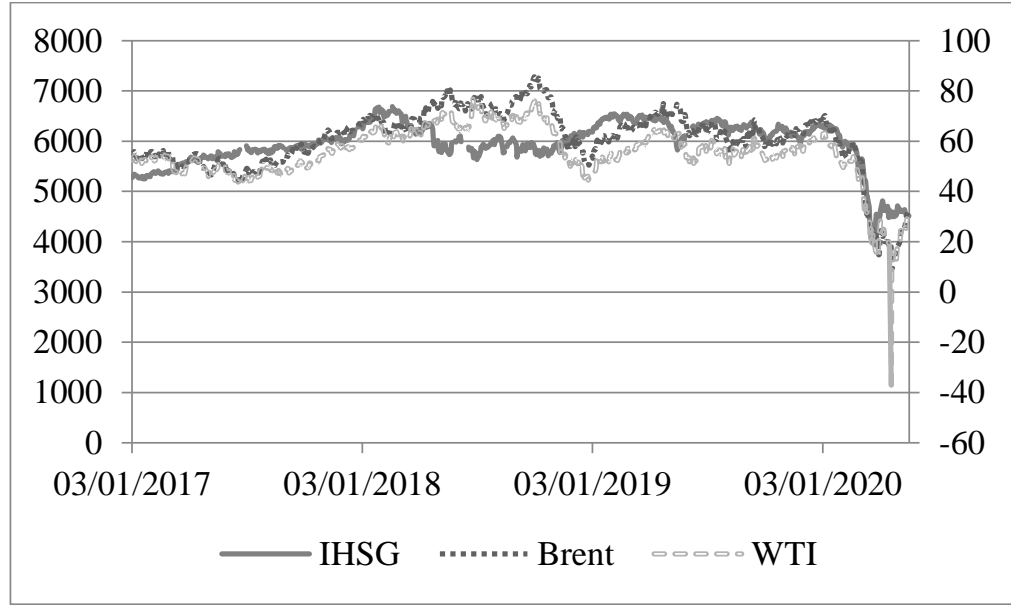

Sumber : U.S EIA dan finance.yahoo.com (Data diolah) Informasi : LHS adalah Indeks Harga Saham Gabungan RHS adalah Harga Minyak Brent dan WTI

\section{Gambar 1. Harga Minyak Dunia-IHSG}

Gambar 1. menunjukkan fenomena pergerakan IHSG setiap harinya bergerak secara dinamis, dimana IHSG cenderung cepat berubah sesuai dengan adanya perubahan harga minyak WTI dan Brent. Pada tahun 2020 harga minyak terus mengalami penurunan yang diakibatkan kelebihan pasokan dimana dimasa pandemi Covid-19 ini yang membuat aktivitas sosial masyarakat turun sehingga pemakaian minyak rendah yang membuat demand minyak rendah (Safitri, 2020). Pelemahan indeks disebabkan IHSG mendapat efek kejut dari penurunan harga minyak yang sempat menyentuh level negatif (di bawah US\$ 0 per barel) yang juga turut mengguncang bursa dunia. Dimana minyak WTI sempat menyentuh level US\$ $-37,63$ per barel yang merupakan harga minyak terendah sepanjang sejarah. IHSG tertekan oleh kecemasan investor terhadap perbaikan harga minyak dunia yang berimbas pada ketidakstabilan harga komoditas, yang artinya harga minyak dunia dapat mempengaruhi IHSG.

Dari hasil penelitian terdahulu oleh Basit (2020) serta Handiani (2014) menunjukkan bahwa harga minyak memiliki hubungan pada IHSG. Namun hal ini bertentangan dengan 
penelitian yang dilakukan Istamar, Sarfiah, \& Rusmijati (2019) serta Raraga, Chabachib, \& Muharam (2012) yang menemukan minyak tidak memiliki hubungan terhadap IHSG. Berbagai penelitian yang telah dilakukan sebelumnya mengenai hubungan antara perubahan harga minyak dengan pasar saham sebagian besar masih menggunakan pendekatan statis atau pendekatan yang menguji ada tidaknya hubungan jangka panjang atau jangka pendek. Oleh karena itu tinjauan dengan pendekatan dinamis belum pernah dilakukan di pasar modal Indonesia pada 9 sektor industri pada Indeks Sektoral di Bursa Efek Indonesia (BEI).

Penelitian ini akan mengkaji hubungan pergerakan harga minyak dunia dengan Indeks Harga Saham Sektoral di 9 sektor industri, seperti: Sektor Pertambangan, Sektor Pertanian, Sektor Industri Kimia Dasar, Sektor Industri Barang Konsumsi, Sektor Aneka, Sektor Properti Real Estate, Sektor Keuangan, Sektor Infrastruktur, Transportasi dan Utilitas serta Sektor Investasi, Jasa dan Perdagangan dengan menggunakan pendekatan dinamis seperti DCCGARCH. DCC-GARCH digunakan dalam penelitian ini karena DCC-GARCH telah terbukti dapat diperkirakan secara berturut-turut untuk matriks kovarians yang bervariasi waktu (Filis, Degiannakis, \& Floros, 2011; Robiyanto, Wahyudi, \& Pangestuti, 2017) meskipun ada beberapa metode yang bisa melakukannya seperti Orthogonal-GARCH (Robiyanto, 2017), dan DCCGARCH (Arouri, Lahiani, \& Nguyen, 2015).

Berdasarkan pada uraian di atas dapat diambil suatu rumusan masalah yaitu "Bagaimana korelasi dinamis antara pergerakan harga minyak dunia (WTI dan Brent) terhadap Indeks Harga Saham Sektoral di Bursa Efek Indonesia (BEI) dengan periode penelitian dari bulan Januari 2017 hingga bulan Juni 2020". Penelitian ini bertujuan untuk mengetahui korelasi dinamis pergerakan harga minyak dunia dengan 9 sektor industri pada Indeks Sektoral di Bursa Efek Indonesia (BEI), sehingga ke depan dapat dijadikan sebagai referensi investor dalam negeri maupun luar negeri yang ingin melakukan investasi pada saham di Indonesia dengan fokus memperhatikan korelasi harga minyak dunia pada kondisi pasar yang dinamis.

\section{KAJIAN LITERATUR}

\subsection{Indeks Saham Sektoral}

Indeks saham adalah kumpulan dari bermacam-macam saham emiten di berbagai bidang industri. Dikarenakan banyaknya jenis saham maka perlu dikelompokkan dalam klasifikasi industri tertentu. Tujuannya untuk membantu investor dalam mengamati kecenderungan pergerakan suatu indeks saham, sehingga dapat melihat kinerja harga secara umum atas saham yang akan dibeli maupun yang sudah dimiliki. Di Bursa Efek Indonesia (BEI) terdapat berbagai macam indeks salah satunya adalah Indeks Saham Sektoral. Klasifikasi sektor industri ini disebut JASICA (Jakarta Sectoral Industry Classification) (Bursa Efek Indonesia, 2010). Terdapat 9 sektor industri yang termasuk dalam klasifikasi JASICA diantaranya yaitu Sektor Pertambangan, Sektor Pertanian, Sektor Industri Kimia Dasar, Sektor Industri Barang Konsumsi, Sektor Aneka, Sektor Properti Real Estate, Sektor Keuangan, Sektor Infrastruktur, Transportasi dan Utilitas serta Sektor Investasi, Jasa dan Perdagangan.

\subsection{Minyak Dunia}

Komoditas yang sangat berpengaruh pada perekonomian suatu negara adalah minyak mentah. Harga spot pasar minyak digunakan untuk mengukur harga minyak mentah dunia (Gumilang, Hidayat, \& Endang NP, 2014). Satuan alat tukar minyak mentah yang dipakai dan diakui dalam kurs dollar adalah barel yang setara dengan 158,98 liter, hal ini dikarenakan barel 
sudah resmi menggunakan standar ISO 9001:2000. Menurut Malkiel (2011) harga minyak yang menjadi patokan internasional adalah Brent North Sea (Europe Brent) dan West Texas Intermediate (WTI). WTI merupakan minyak berjenis lightweight dan biasanya dijadikan sebagai bahan bakar karena memiliki kadar belerang yang rendah serta memiliki kualitas tinggi. Sedangkan Brent adalah minyak yang dihasilkan oleh Laut Utara dari 15 ladang minyak yang tidak sama. Meskipun mutu dari Brent lebih rendah dari WTI, Brent masih bisa dijadikan bahan bakar dengan menyulingnya terlebih dahulu. Minyak WTI menjadi standar di Amerika dan minyak Brent menjadi standar di Afrika dan Eropa. Mulai tahun 1971 Brent menjadi dasar pembentukan harga hampir $40 \%$ dari nilai minyak di seluruh dunia, khususnya minyak Rusia Urals. Namun pada tahun 2007 nilai keseimbangan ini diubah dan minyak Brent di kuotasi oleh WTI dikarenakan produksi minyak mentah di Laut Utara turun sehingga terjadi penurunan likuiditas serta ketidaktepatan dalam menentukan harga untuk nilai minyak campuran dan minyak lainnya.

\subsection{Hubungan Harga Minyak Dengan Pasar Saham}

Pasca terjadinya krisis minyak (oil shock) pada tahun 1970, berbagai penelitian dilakukan untuk mengkaji dampak perubahan harga minyak terhadap variabel ekonomi riil. Sebagian besar penelitian mengemukakan dengan jatuhnya harga minyak berpengaruh pada aktivitas perekonomian baik negara maju maupun negara berkembang. Sebelum krisis keuangan global pada tahun 2008 terjadi peningkatan minyak secara drastis yang disebabkan oleh tingginya permintaan minyak dari Asia dan risiko geopolitik yang terjadi di Timur, sehingga penelitian pada bidang ini kembali populer (Masih, Peters, \& Mello, 2011).

Alkhateeb \& Sultan (2019) mengatakan bahwa faktor ekonomi termasuk impor ekspor dan produksi konsumsi akan mempengaruhi harga minyak. Pada negara pengekspor minyak, naiknya harga minyak berdampak positif tetapi pada negara pengimpor dan konsumen minyak hal ini memberi dampak negatif. Menurut Bjørnland (2008) kenaikan harga minyak diharapkan memberi dampak positif pada negara tujuan ekspor, karena dapat meningkatkan pendapatan negara, yang diharapkan akan meningkatkan pengeluaran dan investasi, sehingga dapat menciptakan produktivitas yang lebih besar dan pengangguran yang lebih rendah. Pasar saham cenderung merespons secara positif dalam peristiwa semacam itu. Namun memiliki hasil yang sebaliknya pada negara pengimpor minyak.

Penelitian Le \& Chang (2011) mengenai pasar modal menyatakan bahwa pasar saham di Jepang tidak dipengaruhi oleh perubahan harga minyak dunia. Papiez \& Smiech (2012) juga menemukan hal yang sama yaitu tidak terdapat efek perubahan harga minyak pada indeks S \& $\mathrm{P}$ 500. Sedangkan penelitian dilakukan oleh Raraga et al. (2012) menyatakan apabila IHSG tidak berhubungan dengan minyak dunia. Pada saat yang sama, banyak penelitian yang menemukan bahwa ada pengaruh atau hubungan signifikan antara pasar saham dengan perubahan harga minyak dunia.

Penelitian oleh Hussin, Muhammad, Razak, Tha, \& Marwan, (2013); Jubinski \& Lipton (2013); Mensi (2019); Suryanto (2017) menemukan hasil yang sebaliknya. Hasil penelitian Hussin et al., (2013) mengkonfirmasi hal ini dengan menyimpulkan bahwa dalam jangka panjang atau pendek pergerakan harga minyak dunia mempengaruhi FTSE Bursa Malaysia Emas Shariah. Dalam penelitian Jubinski \& Lipton (2013) yang diwakili oleh indeks S \& P 500 menemukan bahwa pengembalian pasar saham dipengaruhi signifikan oleh perubahan harga minyak. 
Sedangkan penelitian oleh Mensi (2019) mengenai manajemen risiko portofolio dan pergerakan dinamis antara minyak mentah dan pasar saham sektor Saudi menunjukkan pergerakan yang signifikan antara minyak mentah dan pasar sektor saham dari waktu ke waktu dan lintas frekuensi. Selain itu, pergerakan tersebut semakin meningkat setelah krisis keuangan global 2008-2009. Di antara lima belas sektor yang diteliti, sektor petrokimia (industri hotel dan pariwisata) adalah sektor yang paling terpengaruh oleh pergerakan harga minyak yang naik. Selain itu, bank, industri pertanian dan makanan, telekomunikasi, media dan industri penerbitan, dan sektor industri perhotelan dan pariwisata tidak terpengaruh oleh penurunan harga minyak setelah pertengahan 2014 dan penelitian oleh Suryanto (2017) menunjukkan bahwa secara parsial maupun simultan harga minyak dan harga emas berpengaruh signifikan terhadap IHSG.

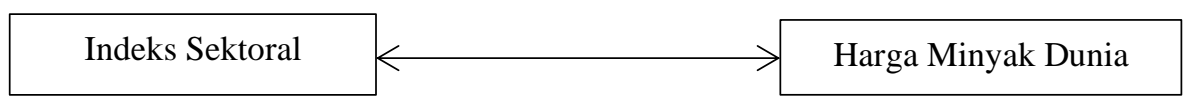

Gambar 2. Kerangka Penelitian

\section{METODE PENELITIAN}

Penelitian ini menggunakan sumber data sekunder berupa data time series frekuensi harian yang dimana closing price minyak dunia (WTI dan Brent) dikumpulkan dari situs resmi U.S. Energy Information Administration (U.S. EIA) dan closing price Indeks Harga Saham Sektoral pada 9 sektor industri seperti Sektor Pertambangan (JKMING), Sektor Pertanian (JKAGRI), Sektor Industri Kimia Dasar (JKBIND), Sektor Industri Barang Konsumsi (JKCONS), Sektor Aneka (JKMISC), Sektor Properti Real Estate (JKPROP), Sektor Keuangan (JKFINA), Sektor Infrastruktur, Transportasi dan Utilitas (JKINFA) serta Sektor Investasi, Jasa dan Perdagangan (JKTRAD) didapat dari finance.yahoo.com periode Januari 2017 sampai Juni 2020. Pada penelitian ini yang menjadi variabel terikat adalah perubahan harga minyak WTI dan Brent. Sedangkan variabel bebas pada penelitian ini adalah 9 sektor industri pada Indeks Harga Saham Sektoral di Bursa Efek Indonesia (BEI).

Perubahan harga minyak dunia dapat dihitung dengan rumus sebagai berikut :

$\Delta \mathrm{OIL}_{\mathrm{t}}=\frac{\mathrm{OIL}_{\mathrm{t}}-\mathrm{OIL}_{\mathrm{t}-1}}{\mathrm{OIL}_{\mathrm{t}-1}}$

Keterangan :

$\Delta \mathrm{OIL}_{t}:$ Perubahan harga minyak hari t

$\mathrm{OIL}_{t} \quad$ : Harga penutupan minyak hari $\mathrm{t}$

$\mathrm{OIL}_{t-1}$ : Harga penutupan minyak hari t-1

Perhitungan return Indeks Harga Saham Sektoral dapat dihitung dengan menggunakan rumus sebagai berikut:

$R_{t}=\frac{\mathrm{I}_{\mathrm{t}}-\mathrm{I}_{\mathrm{t}-1}}{\mathrm{I}_{\mathrm{t}-1}}$

Keterangan :

$R_{t} \quad:$ Return indeks harga saham sektoral hari t

$\mathrm{I}_{\mathrm{t}} \quad$ : Indeks harga saham sektoral hari t

$\mathrm{I}_{\mathrm{t}-1} \quad$ : Indeks harga saham sektoral hari t-1 
Metode yang digunakan dalam penelitian ini adalah Dynamic Conditional CorrelationGeneralized Autoregressive Conditional Heteroscedasticity (DCC-GARCH) yang pertama kali diperkenalkan oleh Engle (2002) dengan spesifikasi seperti berikut ini :

$r_{t} \mid=_{t-1} \sim N\left(0, D_{t} R_{t} D_{t}\right)$

$D_{t}^{2}=\operatorname{diag}\left\{\omega_{i}\right\}+\operatorname{diag}\left\{k_{i}\right\}^{\circ} r_{t-1} r_{t-1}^{\prime}+\operatorname{diag}\left\{\lambda_{i}\right\}^{\circ} D_{t-1}^{2}$

$\varepsilon_{t}=D_{t}^{-1} r_{t}$

$Q_{t}=S^{\circ}\left(\iota \iota^{\prime}-\mathrm{A}-\mathrm{B}\right)+A^{\circ} \varepsilon_{t-1} \varepsilon_{t-1}^{\prime}+B^{\circ} Q_{t-1}$

$R_{t}=\operatorname{diag}\left\{Q_{i}\right\}^{-1} Q_{t} \operatorname{diag}\left\{Q_{i}\right\}^{-1}$.

Untuk logaritma penaksir atau Log Likelihood adalah sebagai berikut :

$\mathrm{L} r_{t}={ }_{t-1} \sim N\left(0, H_{t}\right)$

$\mathrm{L} \quad=-\frac{1}{2} \sum_{t=1}^{T}\left(n \log (2 \pi)+\log \left|H_{t}\right|+r^{\prime}{ }_{t} H_{t}^{-1} r_{t}\right)$

$$
=-\frac{1}{2} \sum_{t=1}^{T}\left(n \log (2 \pi)+\log \left|D_{t} R_{t} D_{t}\right|+r_{t}^{\prime} D_{t}^{-1} R_{t}^{-1} D_{t}^{-1} r_{t}\right)
$$$$
=-\frac{1}{2} \sum_{t=1}^{T}\left(n \log (2 \pi)+2 \log \left|D_{t}\right|+\log \left|R_{t}\right|+\varepsilon_{t}^{\prime} R_{t}^{-1} \varepsilon_{t}\right)
$$$$
=-\frac{1}{2} \sum_{t=1}^{T}\left(n \log (2 \pi)+2 \log \left|D_{t}\right|+r_{t}^{\prime} D_{t}^{-1} D_{t}^{-1} r_{t}-\varepsilon_{t}^{\prime} \varepsilon_{t}+\log \left|R_{t}\right|+\varepsilon_{t}^{\prime} R_{t}^{-1} \varepsilon_{t}\right),
$$

Model tersebut dapat dimaksimalkan dalam parameter model, salah satu tujuannya adalah untuk memudahkan suatu prediksi melalui matriks co-varian yang sangat besar Newey \& Mcfadden (1994) menjelaskan bahwa perumusan model dilakukan ke dalam konsistensi dan normalitas asimtotik dari parameter yang memenuhi syarat, jika parameter D dicatat dengan $\phi$ dan parameter tambahan dalam $\mathrm{R}$ dicatat dengan $\theta$, Log-likelihood dapat dinyatakan sebagai jumlah volatilitas parsial dan korelasi sebagai berikut : $\mathrm{L}(\theta, \phi)=\mathrm{L}_{\mathrm{V}}(\theta)+\mathrm{L}_{\mathrm{C}}(\theta, \phi)$

Rumus dari volatilitas adalah sebagai berikut :

$L_{V}(\theta)=-\frac{1}{2} \sum_{t}\left(n \log (2 \pi)+\log \left|D_{t}\right|^{2}+r_{t}^{\prime} D_{t}^{-2} r_{t}\right)$

Komponen dari korelasi adalah sebagai berikut :

$L_{C}(\theta, \phi)=-\frac{1}{2} \sum_{t}\left(\log \left|R_{t}\right|+\varepsilon_{t}^{\prime} R_{t}^{-1} \varepsilon_{t}-\varepsilon_{t}^{\prime} \varepsilon_{t}\right)$

Partital volatilitas adalah jumlah dari GARCH likelihood tiap individu :

$L_{V}=-\frac{1}{2} \sum_{t} \sum_{i=1}^{n}\left(\log (2 \pi)+\log \left(h_{i, t}\right)+\frac{r_{i, t}^{2}}{h_{i, t}}\right)$

Jika digabungkan dapat dimaksimalkan dengan mengoptimalkan setiap istilah. Bagian kedua dari kemungkinan dilakukan untuk memperkirakan parameter korelasi. Mempertimbangkan residu kuadrat ini tidak terikat dengan parameter ini, sehingga hal-hal itu tidak dapat terlibat dalam kondisi urutan pertama dan harus diabaikan. Estimator yang dihasilkan kemudian disebut DCC LL INT, karena menggunakan model terintegrasi. Pendekatan dua langkah untuk mengoptimalkan kemungkinan digunakan untuk menghasilkan :

$(\hat{\theta})=\arg \max \left(L_{V}(\theta)\right)$ 
Nilai tersebut melangkah pada step ke dua: $\max _{\phi}\left\{L_{C}(\widehat{\theta}, \phi)\right\}$

Model DCC-GARCH juga telah digunakan oleh Robiyanto et al. (2017) dalam mempelajari hubungan dinamis antara pasar saham Indonesia dan pasar saham Malaysia dengan harga emas, sedangkan variasi model GARCH seperti OGARCH (Orthogonal Generalized Autoregressive Conditional Heteroscedasticity) juga telah digunakan oleh Robiyanto (2017). Penelitian ini tidak menggunakan panel GARCH yang diusulkan oleh Cermeño \& Grier (2001), karena penelitian ini mencoba menguji korelasi yang bervariasi waktu untuk seri waktu tunggal untuk setiap pasar saham yang diteliti. Perhitungan DCC-GARCH dilakukan dengan menggunakan Software Eviews 9.

\section{HASIL DAN PEMBAHASAN}

\subsection{Hasil Uji Data Stasioner}

Pengujian data stasioner dilakukan dengan uji Augmented Dickey-Fuller (ADF) yang dapat dilihat pada Tabel 1. Berdasarkan pada Tabel 1. dapat disimpulkan bahwa semua nilai statistik Augmented Dickey-Fuller pada return (First Difference), semua variabel yang digunakan dalam penelitian ini signifikan pada tingkat signifikansi 1 persen sehingga menunjukkan bahwa semua data yang digunakan stasioner.

Tabel 1. Hasil Uji Augmented Dicky-Fuller pada return (First Difference)

\begin{tabular}{cc}
\hline Variabel & Statistik Augmented Dickey-Fuller \\
\hline WTI & $-21,22886$ \\
BRENT & $-5,78721$ \\
JKAGRI & $-25,22134$ \\
JKBIND & $-25,46965$ \\
JKCONS & $-22,83450$ \\
JKFINA & $-25,30435$ \\
JKINFA & $-22,49309$ \\
JKMING & $-26,13863$ \\
JKMISC & $-27,98656$ \\
JKPROP & $-25,52827$ \\
JKTRAD & $-29,82504$ \\
\hline
\end{tabular}

Catatan : *Tingkat signifikansi statistik sebesar $1 \%$

\subsection{Korelasi Dinamis Harga Minyak Dunia dengan Indeks Sektor Pertanian (JKAGRI) dengan Variasi Waktu}

Berdasarkan uji yang dilakukan dengan menggunakan teknik analisis DCC-GARCH antara harga minyak dunia dengan Sektor Pertanian, dapat dilihat pada Gambar 3. Pada Gambar 3a. menunjukkan hasil nilai DCC antara Brent-JKAGRI dimana selama periode penelitian berada pada kisaran -0,25441 hingga 0,49950. Nilai terendah terjadi pada bulan Agustus 2018 dan nilai tertinggi terjadi pada bulan Maret 2020. Sedangkan Gambar 3b. menunjukkan nilai DCC antara harga minyak WTI-JKAGRI selama periode penelitian berada pada kisaran -0,19891 hingga 0,23000. Nilai terendah terjadi pada bulan Agustus 2018 dan nilai tertinggi terjadi pada bulan Maret 2020. Pada Tabel 2. dapat dilihat juga bahwa rata-rata nilai DCC Brent-JKAGRI lebih tinggi dengan nilai 0,07234 dibandingkan rata-rata nilai DCC WTI JKAGRI sebesar 0,02454. Hal tersebut menunjukkan jika korelasi dinamis Brent-JKAGRI lebih kuat dibandingkan WTI- 
JKAGRI. Namun secara keseluruhan korelasi dinamis antara WTI dan Brent dengan Indeks Sektor Pertanian adalah positif tetapi masih sangatlah lemah.

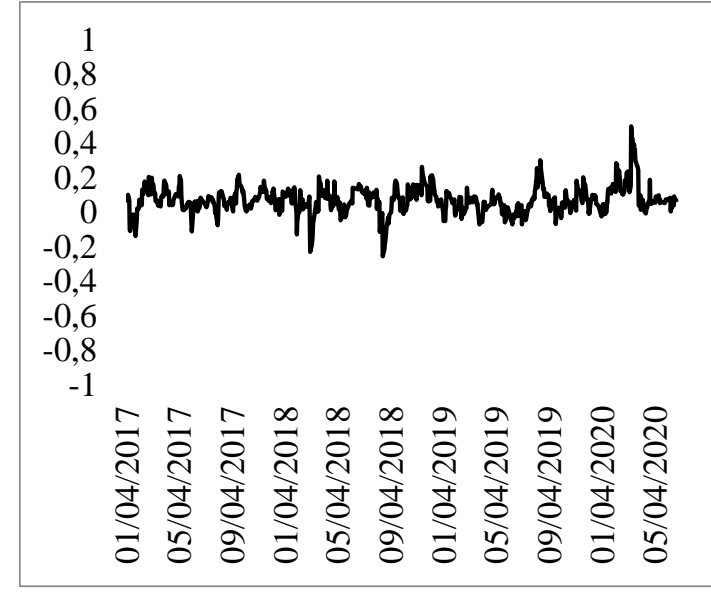

Gambar 3a. Brent-JKAGRI

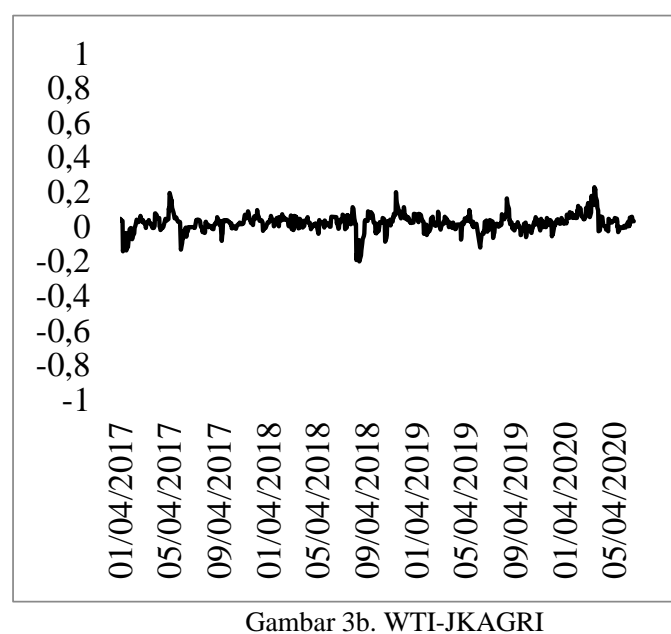

Gambar 3b. WTI-JKAGRI

Gambar 3. Korelasi Dinamis Harga Minyak Dunia-Sektor Pertanian

\subsection{Korelasi Dinamis Harga Minyak Dunia dengan Indeks Sektor Industri Kimia Dasar (JKBIND)}

Berdasarkan pengujian antara harga minyak dunia dengan Sektor Industri Kimia Dasar menggunakan teknik DCC-GARCH, dapat dilihat pada Gambar 4. Pada Gambar 4a. menunjukkan bahwa nilai DCC antara harga minyak Brent-JKBIND dimana selama periode penelitian berada pada kisaran -0,11349 hingga 0,49924. Nilai terendah terjadi pada bulan Februari 2017 dan nilai tertinggi terjadi pada bulan Maret 2020. Sedangkan pada Gambar 4b. nilai DCC antara WTI-JKBIND selama periode penelitian berada pada kisaran -0,03786 hingga 0,12991. Nilai terendah terjadi pada bulan Juni 2019 dan nilai tertinggi terjadi pada bulan Maret 2020. Pada Tabel 2. dapat dilihat juga bahwa rata-rata nilai DCC Brent-JKBIND dimana nilainya 0,06782 lebih tinggi dibandingkan rata-rata nilai DCC WTI-JKBIND sebesar 0,02837. Hal tersebut menunjukkan jika korelasi dinamis Brent-JKBIND lebih kuat. Namun secara keseluruhan korelasi dinamis antara WTI dan Brent dengan Indeks Sektor Industri Kimia Dasar adalah positif tetapi masih sangatlah lemah.

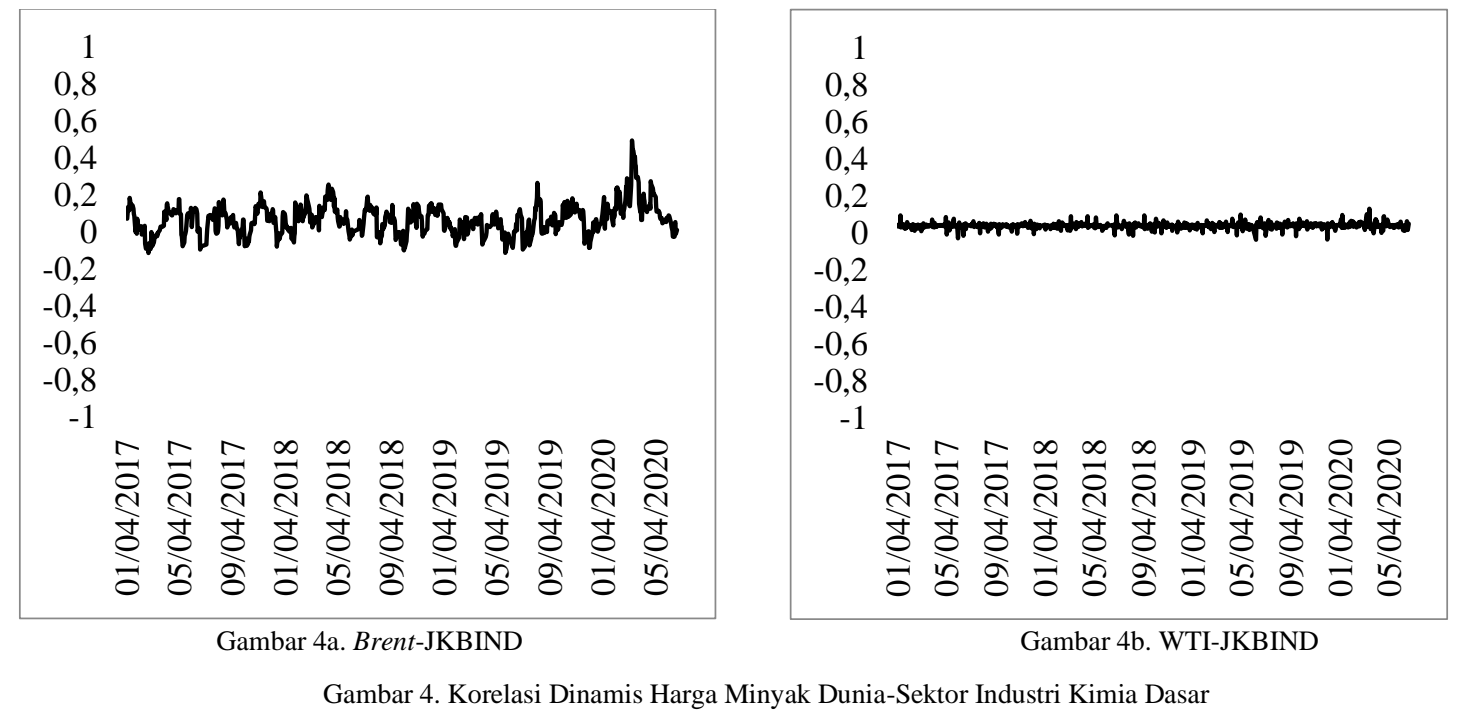




\subsection{Korelasi Dinamis Harga Minyak Dunia dengan Indeks Sektor Barang Konsumsi (JKCONS)}

Hasil uji menggunakan teknik analisis DCC-GARCH antara harga minyak dunia dengan Indeks Sektor Barang Konsumsi dapat dilihat pada Gambar 5. sebagai berikut :

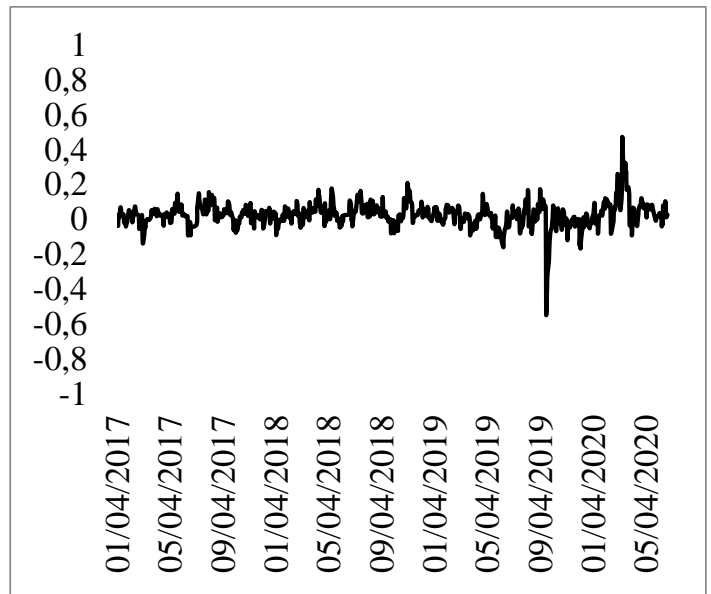

Gambar 5a. Brent-JKCONS

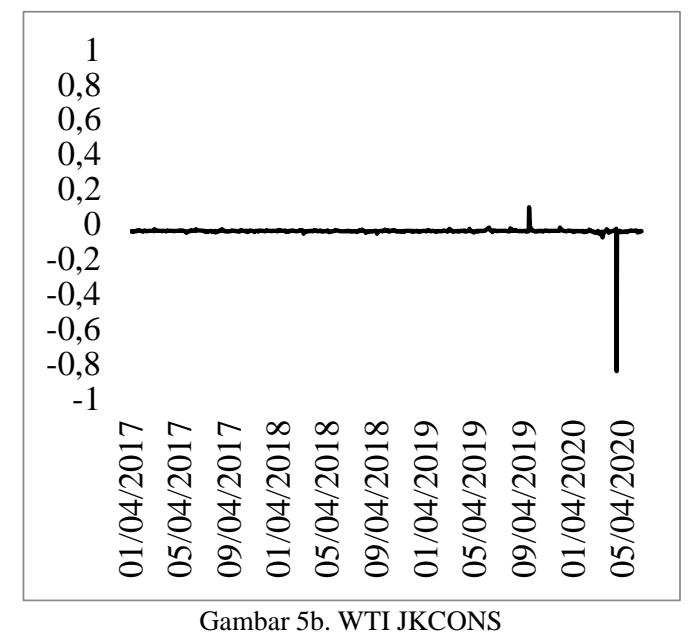

Gambar 5b. WTI JKCONS

Gambar 5. Korelasi Dinamis Harga Minyak Dunia-Sektor Barang Konsumsi

Pada Gambar 5a. hasil nilai DCC antara Brent-JKCONS selama periode penelitian berada pada kisaran -0,54821 hingga 0,47327. Nilai terendah terjadi pada bulan September 2019 dan nilai tertinggi terjadi pada bulan Maret 2020. Sedangkan nilai DCC antara harga minyak WTI-JKCONS selama periode penelitian dapat dilihat pada Gambar 5b. yaitu berada pada kisaran -0,84067 hingga 0,09871. Nilai terendah terjadi pada bulan April 2020 dan nilai tertinggi terjadi pada bulan September 2019. Hasil DCC WTI-JKCONS turun ekstrim semenjak adanya coronavirus yang menyebabkan pemberlakuan lockdown di sebagian besar negara konsumsi minyak, sehingga permintaan terhadap minyak turun drastis namun tidak diiringi penurunan produksi sehingga stok minyak meningkat dan berdampak pada harga minyak yang turun signifikan. Alghalith (2010) menunjukkan secara empiris bahwa peningkatan pasokan minyak menurunkan harga pangan. Namun secara keseluruhan korelasi dinamis antara minyak dunia dengan JKCONS menunjukkan korelasi yang masih sangat lemah, dapat dilihat pada Tabel 2. jika rata-rata nilai DCC antara Brent-JKCONS yang memiliki korelasi positif sebesar 0,2828 dan rata-rata nilai DCC antara WTI-JKCONS menunjukkan korelasi yang negatif yaitu sebesar $-0,03852$.

\subsection{Korelasi Dinamis Harga Minyak Dunia dengan Indeks Sektor Keuangan (JKFINA)}

Pada Gambar 6. berikut dapat dilihat hasil analisis antara harga minyak dunia dengan Indeks Sektor Keuangan menggunakan DCC-GARCH. Nilai DCC antara Brent-JKFINA dapat dilihat pada Gambar 6a. dimana selama periode penelitian hasilnya berada pada kisaran -0,40203 hingga 0,61490. Nilai terendah terjadi pada bulan September 2019 dan nilai tertinggi terjadi pada bulan Maret 2020. Sedangkan nilai DCC WTI-JKFINA dapat dilihat pada Gambar 6b. bahwa selama periode penelitian berada nilainya pada kisaran $-0,12017$ hingga 0,11011 . Nilai terendah terjadi pada bulan September 2019 dan nilai tertinggi terjadi pada bulan Maret 2020. Berdasarkan Tabel 2. dapat dilihat juga bahwa rata-rata nilai DCC Brent-JKFINA dimana nilainya 0,04346 lebih tinggi jika dibandingkan rata-rata nilai DCC WTI-JKFINA sebesar 0,02570. Hal tersebut menunjukkan jika korelasi dinamis Brent-JKFINA lebih kuat dari WTI- 
JKFINA. Namun secara keseluruhan korelasi dinamis antara WTI dan Brent dengan Indeks Sektor Keuangan adalah positif tetapi masih sangatlah lemah.

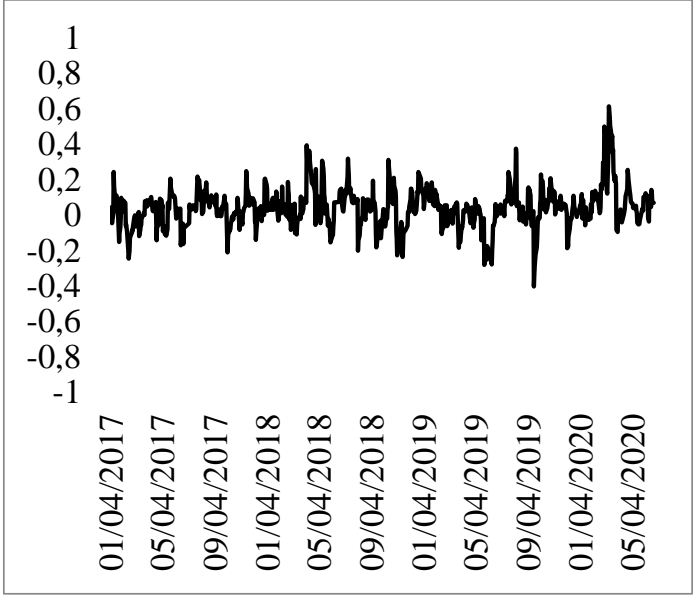

Gambar 6a. Brent-JKFINA

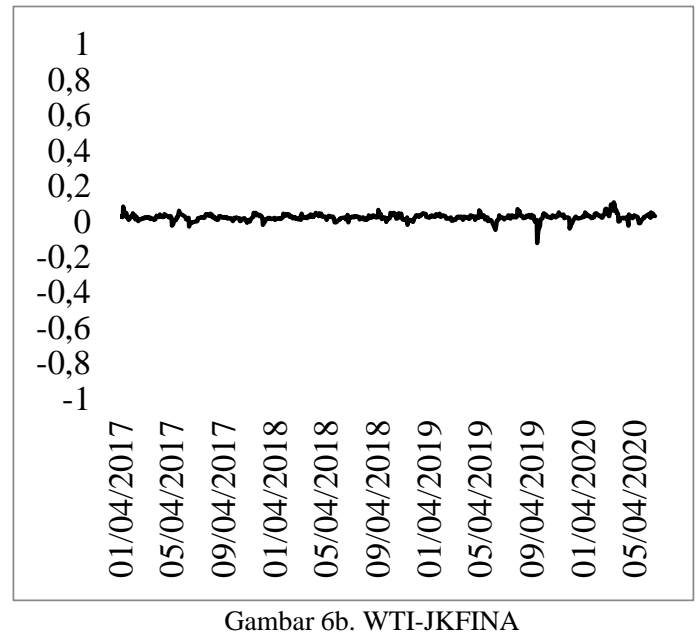

Gambar 6b. WTI-JKFINA

Gambar 6. Korelasi Dinamis Harga Minyak Dunia-Sektor Keuangan

\subsection{Korelasi Dinamis Harga Minyak Dunia dengan Indeks Sektor Infrastruktur, Transportasi dan Utilitas (JKINFA)}

Hasil uji DCC-GARCH antara harga minyak dunia dengan Indeks Sektor Infrastruktur, Transportasi dan Utilitas dapat dilihat pada Gambar 7. Pada Gambar 7a. menunjukkan hasil analisis dengan menggunakan DCC-GARCH antara Brent-JKINFA bahwa selama periode penelitian berada pada kisaran $-0,38309$ hingga 0,62844 . Nilai terendah terjadi pada bulan Januari 2017 dan nilai tertinggi terjadi pada bulan Maret 2020. Gambar 7b. menunjukkan hasil nilai DCC antara WTI-JKINFA bahwa selama periode penelitian berada pada kisaran 0,02328 hingga 0,05726. Nilai terendah terjadi pada bulan April 2020 dan nilai tertinggi terjadi pada bulan Maret 2020. Pada Tabel 2. dapat dilihat juga bahwa rata-rata nilai DCC antara WTIJKINFA dengan Brent-JKINFA lebih tinggi rata-rata nilai DCC Brent-JKINFA dimana nilainya 0,06923 dibandingkan rata-rata nilai DCC WTI-JKINFA sebesar 0,03796. Hal tersebut menun-

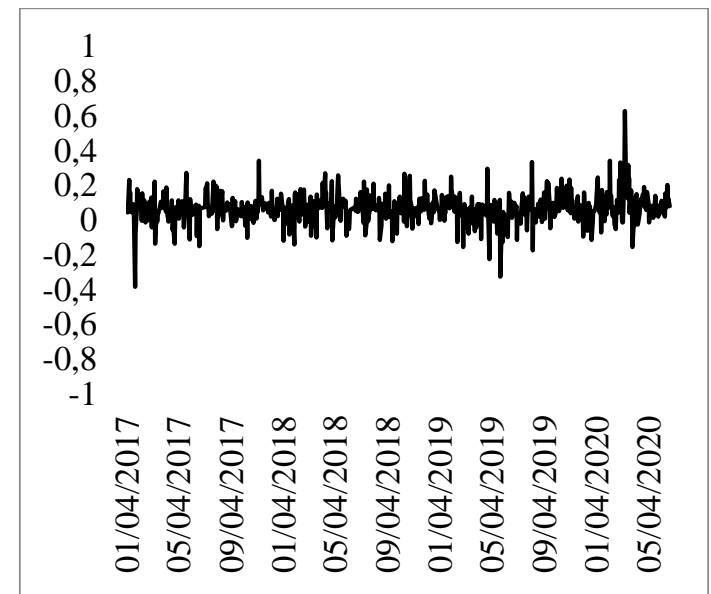

Gambar 7a. Brent-JKINFA

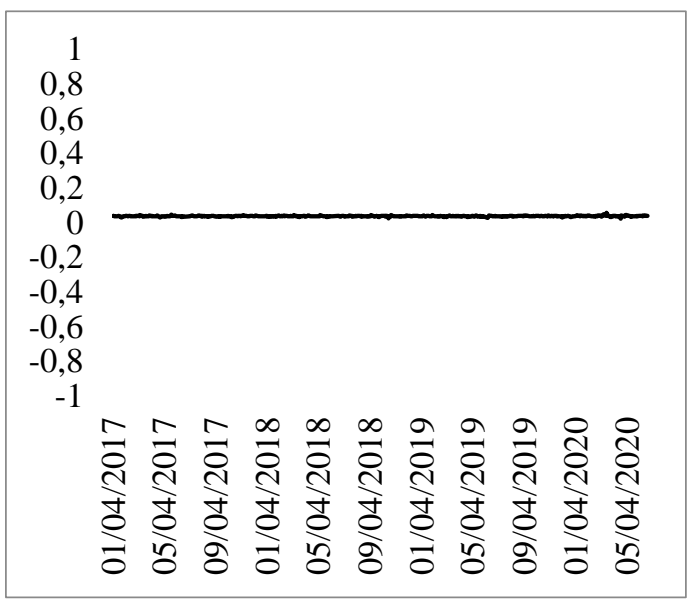

Gambar 7b. WTI-JKINFA

Gambar 7. Korelasi Dinamis Harga Minyak Dunia- Sektor Infrastruktur, Transportasi dan Utilitas 
jukkan jika korelasi dinamis Brent-JKINFA lebih kuat dibandingkan WTI-JKINFA. Namun secara keseluruhan korelasi dinamis antara WTI dan Brent dengan Indeks Sektor Infrastruktur, Transportasi dan Utilitas adalah positif tetapi masih sangatlah lemah.

\subsection{Korelasi Dinamis Harga Minyak Dunia dengan Indeks Sektor Pertambangan (JKMING)}

Hasil analisis DCC-GARCH antara harga minyak dunia dengan Indeks Sektor Pertambangan dapat dilihat pada Gambar 8. berikut :

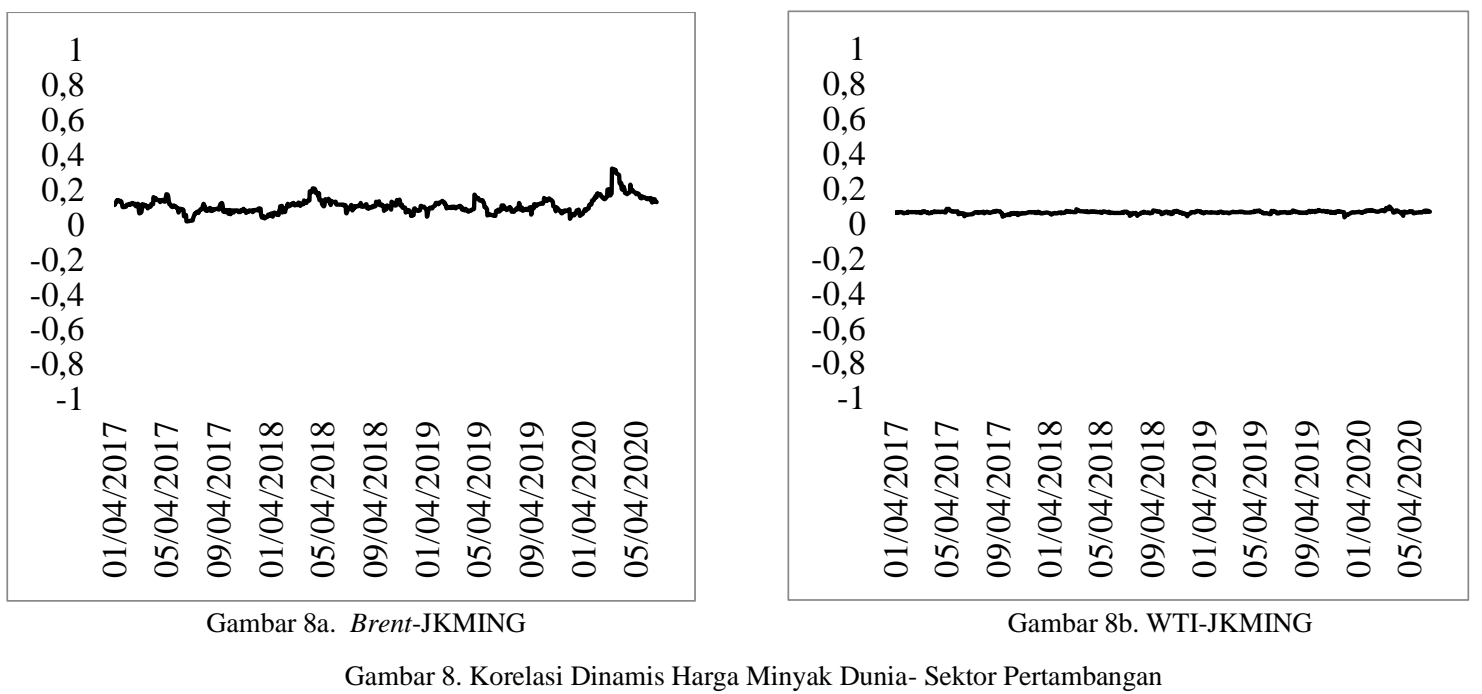

Hasil nilai DCC Brent-JKMING dapat dilihat pada Gambar 8a. yang menunjukkan bahwa selama periode penelitian nilai DCC berada pada kisaran 0,02006 hingga 0,32304. Nilai terendah terjadi pada bulan Juni 2017 dan nilai tertinggi terjadi pada bulan Maret 2020. Sedangkan nilai DCC WTI-JKMING dilihat pada Gambar 8b. bahwa selama periode penelitian berada pada kisaran 0,03845 hingga 0,09942. Nilai terendah terjadi pada bulan Desember 2019 dan nilai tertinggi terjadi pada bulan Maret 2020. Pada Tabel 2. dapat dilihat juga bahwa rata-rata nilai DCC Brent-JKMING dimana nilainya 0,11249 lebih tinggi dibandingkan rata-rata nilai DCC WTI-JKMING sebesar 0,06745. Hal tersebut menunjukkan jika korelasi dinamis BrentJKMING lebih kuat dibandingkan WTI-JKMING. Namun secara keseluruhan korelasi dinamis antara Minyak WTI dan Brent dengan Indeks Sektor Pertambangan adalah positif tetapi masih sangat lemah.

\subsection{Korelasi Dinamis Harga Minyak Dunia dengan Indeks Sektor Aneka (JKMISC)}

Pada Gambar 9. berikut ini dapat dilihat hasil DCC-GARCH antara harga minyak dunia dengan Indeks Sektor Aneka. Pada Gambar 9a. menunjukkan nilai DCC Brent-JKMISC bahwa selama periode penelitian berada pada kisaran $-0,21886$ hingga 0,68283 . Nilai terendah terjadi pada bulan Juni 2017 dan nilai tertinggi terjadi pada bulan Maret 2020. Sedangkan Gambar 9b. menunjukkan nilai DCC antara WTI-JKMISC bahwa selama periode penelitian nilainya berada pada kisaran $-0,11155$ hingga 0,25584 . Nilai terendah terjadi pada bulan Juli 2018 dan nilai tertinggi terjadi pada bulan Maret 2020. Pada Tabel 2. dapat dilihat juga bahwa rata-rata nilai DCC antara WTI-JKMISC dengan Brent-JKMISC lebih tinggi rata-rata nilai DCC BrentJKMISC dimana nilainya 0,05666 dibandingkan rata-rata nilai DCC WTI-JKMISC sebesar 0,02737. Hal tersebut menunjukkan jika korelasi dinamis Brent-JKMISC lebih kuat 
dibandingkan WTI-JKMISC. Namun secara keseluruhan menunjukkan bahwa korelasi dinamis antara Minyak WTI dan Brent dengan Indeks Sektor Aneka adalah positif dan sangat lemah.

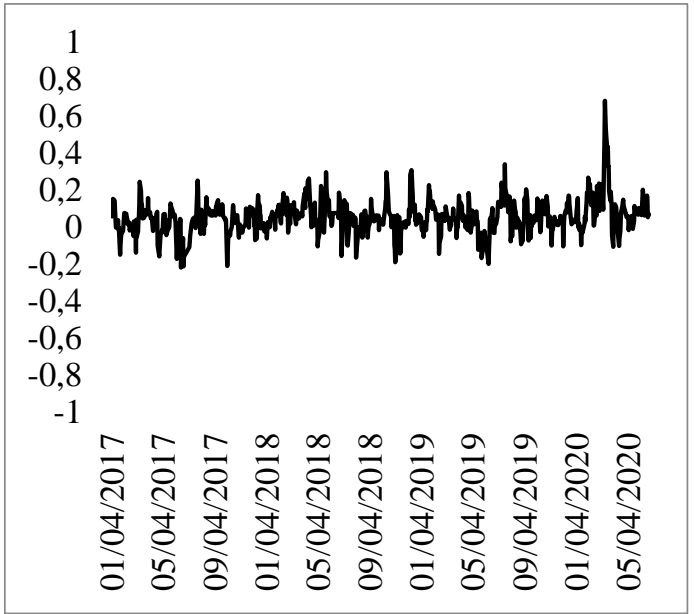

Gambar 9a. Brent-JKMISC

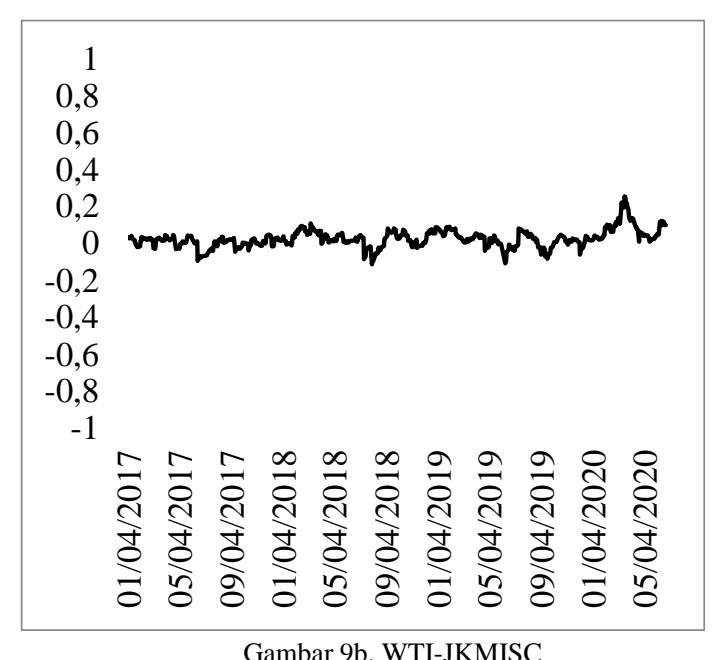

Gambar 9b. WTI-JKMISC

Gambar 9. Korelasi Dinamis Harga Minyak Dunia- Sektor Aneka

\subsection{Korelasi Dinamis Harga Minyak Dunia dengan Indeks Sektor Properti Real Estate (JKPROP)}

Gambar 10. berikut merupakan hasil DCC-GARCH antara harga minyak dunia dengan Indeks Sektor Properti Real Estate. Pada Gambar 10a. hasil menunjukkan bahwa nilai DCC Brent-JKPROP selama periode penelitian berada pada kisaran $-0,26545$ hingga 0,72578 . Nilai terendah terjadi pada bulan September 2019 dan nilai tertinggi terjadi pada bulan Maret 2020. Sedangkan Gambar 10b. menunjukkan bahwa nilai DCC antara WTI-JKPROP selama periode penelitian berada pada kisaran $-0,00273$ hingga 0,20023 . Nilai terendah terjadi pada bulan Desember 2019 dan nilai tertinggi terjadi pada bulan Maret 2020. Dapat dilihat juga pada Tabel 2. bahwa rata-rata nilai DCC antara WTI-JKPROP dengan Brent-JKPROP lebih tinggi rata-rata nilai DCC WTI-JKPROP dimana nilainya 0,10295 dibandingkan rata-rata nilai DCC BrentJKPROP sebesar 0,10186. Hal tersebut menunjukkan jika korelasi dinamis antara WTI-JKPROP lebih kuat. Akan tetapi secara keseluruhan menunjukkan bahwa korelasi dinamis antara Minyak WTI dan Brent dengan Indeks Sektor Properti Real Estate adalah sangat lemah dan positif.

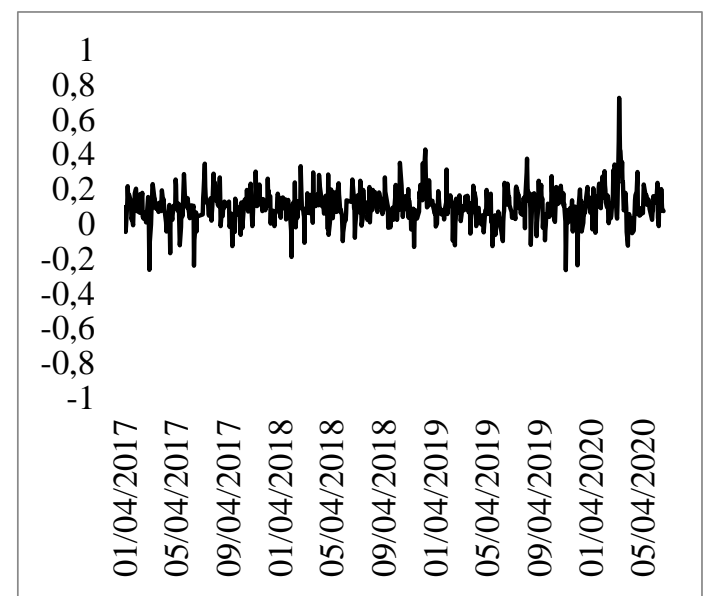

Gambar 10a. Brent-JKPROP

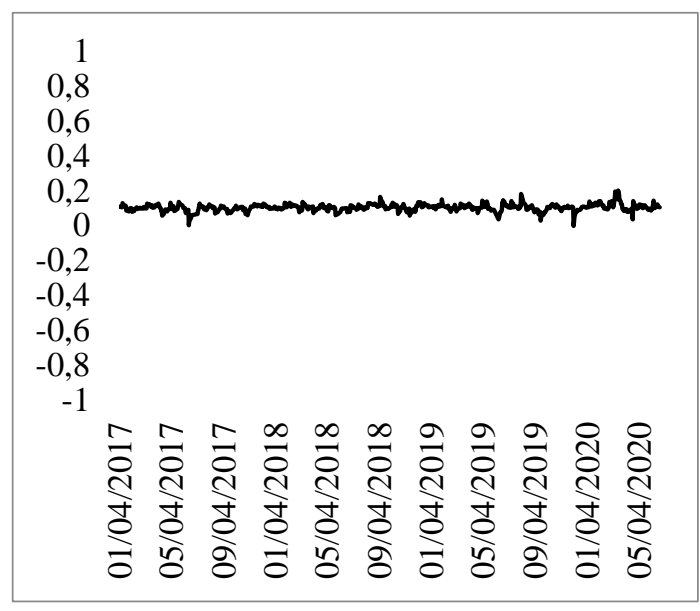

Gambar 10b. WTI-JKPROP 


\subsection{Korelasi Dinamis Harga Minyak Dunia dengan Indeks Sektor Investasi, Jasa dan Perdagangan (JKTRAD)}

Hasil uji DCC GARCH antara harga minyak dengan Indeks Sektor Investasi, Jasa dan Perdagangan ditunjukkan oleh Gambar 11. berikut ini :

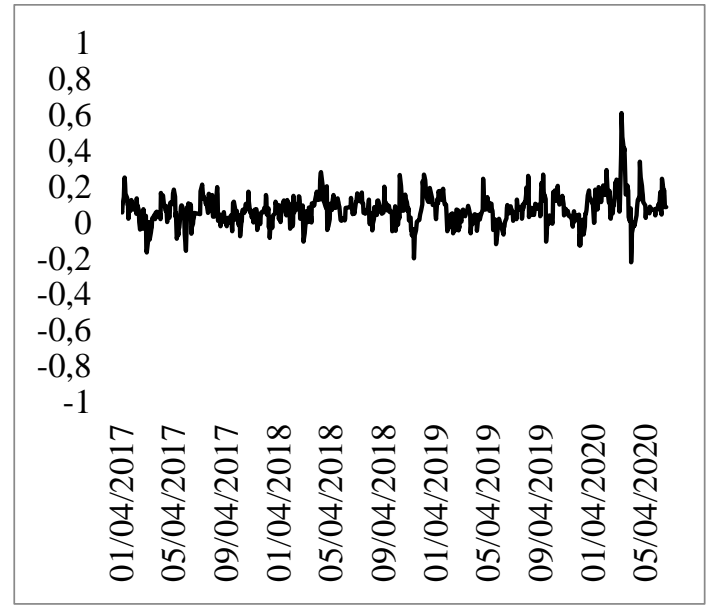

Gambar 11a. Brent-JKTRAD

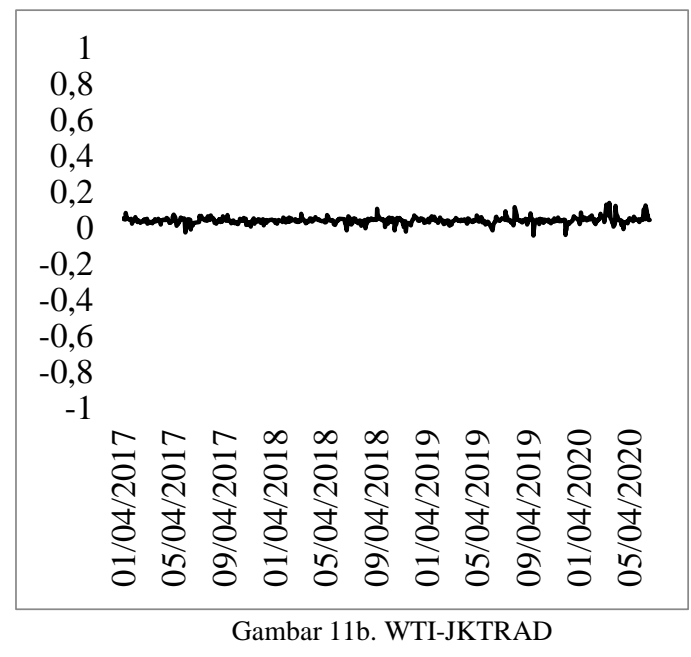

Gambar 11b. WTI-JKTRAD

Gambar 11. Korelasi Dinamis Harga Minyak Dunia- Sektor Investasi, Jasa dan Perdagangan

Pada Gambar 11a. menunjukkan hasil nilai DCC antara Brent-JKTRAD selama periode penelitian berada pada kisaran -0,22013 hingga 0,61033. Nilai terendah terjadi pada bulan April 2020 dan nilai tertinggi terjadi pada bulan Maret 2020. Gambar 11b. menunjukkan nilai DCC WTI-JKTRAD bahwa selama periode penelitian berada pada kisaran -0,04194 hingga 0,14023. Nilai terendah terjadi pada bulan September 2019 dan nilai tertinggi terjadi pada bulan Maret 2020. Berdasarkan pada Tabel 2. dapat dilihat juga bahwa rata-rata nilai DCC Brent-JKTRAD dimana nilainya 0,07542 lebih tinggi dibandingkan rata-rata nilai DCC WTI-JKTRAD sebesar 0,04285. Hal tersebut menunjukkan jika korelasi dinamis Brent -JKTRAD lebih kuat dibandingkan WTI-JKTRAD. Akan tetapi secara keseluruhan menunjukkan bahwa korelasi dinamis antara Minyak WTI dan Brent dengan Indeks Sektor Investasi, Jasa dan Perdagangan adalah sangat lemah dan positif.

\subsection{Diskusi}

Rangkuman hasil analisis DCC antara harga minyak dunia dengan Indeks Sektoral yang terdaftar di Bursa Efek Indonesia (BEI) dapat dilihat pada Tabel 2. yang menunjukkan bahwa kondisi korelasi dinamis antara nilai pergerakan harga minyak dunia dan Indeks Harga Saham Sektoral mencerminkan suatu kondisi yang tidak sama, korelasi Indeks Sektoral dengan Brent lebih tinggi dibandingkan korelasinya dengan WTI. Hal ini disebabkan mulai Juli 2016 Kementerian Energi dan Sumber Daya Mineral (ESDM) menggunakan referensi Brent sebagai basis perhitungan harga minyak mentah Indonesia atau ICP (Gumelar, 2016). Sejalan juga dengan temuan Hersugondo et al. (2015) yang melakukan penelitian di pasar saham Malaysia dan Thailand tidak memiliki korelasi dengan perubahan WTI. Secara keseluruhan korelasi harga minyak dunia dan Indeks Sektoral adalah lemah. Menurut Arouri (2011) mengatakan korelasi perubahan harga minyak dunia yang lemah pada semua sektor baik pada sektor yang berkaitan langsung dengan minyak maupun tidak berkaitan erat, hal tersebut menandakan bahwa reaksi pasar modal tidak hanya berfokus pada kemungkinan perubahan biaya produksi karena 
peningkatan atau penurunan harga minyak dunia melainkan juga melihat kepercayaan konsumen, permintaan akan barang, pertumbuhan ekonomi serta faktor makro ekonomi lainnya.

Tabel 2. Korelasi Dinamis antara Minyak Dunia (Brent dan WTI) dengan Indeks Sektoral yang terdaftar di Bursa Efek Indonesia (BEI) dengan Variasi Waktu

\begin{tabular}{lcccc}
\hline & Rata-Rata & Maksimum & Minimum & Std. Dev \\
\hline BRENT-JKAGRI & 0,07234 & 0,49950 & $-0,25441$ & 0,07901 \\
BRENT-JKBIND & 0,06782 & 0,49524 & $-0,11349$ & 0,08290 \\
BRENT-JKCONS & 0,02828 & 0,47327 & $-0,54821$ & 0,07216 \\
BRENT-JKFINA & 0,04346 & 0,61490 & $-0,40203$ & 0,11153 \\
BRENT-JKINFA & 0,06923 & 0,62844 & $-0,38309$ & 0,07693 \\
BRENT-JKMING & 0,11249 & 0,32308 & 0,02006 & 0,04291 \\
BRENT-JKMISC & 0,05666 & 0,68283 & $-0,21886$ & 0,09203 \\
BRENT-JKPROP & 0,10186 & 0,72578 & $-0,26546$ & 0,09173 \\
BRENT-JKTRAD & 0,07542 & 0,61033 & $-0,22013$ & 0,08297 \\
WTI-JKAGRI & 0,02454 & 0,23000 & $-0,19891$ & 0,04734 \\
WTI-JKBIND & 0,02837 & 0,12991 & $-0,03786$ & 0,01525 \\
WTI-JKCONS & $-0,03852$ & 0,09871 & $-0,84067$ & 0,02888 \\
WTI-JKFINA & 0,02570 & 0,11011 & $-0,12017$ & 0,01776 \\
WTI-JKINFA & 0,03796 & 0,05726 & 0,02328 & 0,00234 \\
WTI-JKMING & 0,06745 & 0,09946 & 0,03845 & 0,00674 \\
WTI-JKMISC & 0,02737 & 0,25584 & $-0,11155$ & 0,04788 \\
WTI-JKPROP & 0,10295 & 0,20023 & $-0,00273$ & 0,02054 \\
WTI-JKTRAD & 0,04285 & 0,14023 & $-0,04194$ & 0,01713 \\
\hline
\end{tabular}

Sektor Pertanian memiliki korelasi positif dengan minyak dunia hal ini dikarenakan menurut Riga, Indriana, \& Rahmanto (2016) apabila harga minyak dunia naik akan menyebabkan demand-side effect yang memungkinkan investor pada komoditas memilih alternatif investasi pada komoditas pertanian. Dengan adanya demand-side effect pada komoditas pertanian, permintaan saham pada Sektor Pertanian meningkat dan akan berpengaruh terhadap Indeks Sektor Pertanian. Harga minyak dunia juga mempunyai korelasi positif pada Sektor Industri Kimia Dasar. Dimana Sektor Industri Kimia Dasar yang kegiatannya meliputi pemurnian logam dasar dan mulia, produsen bahan kimia dan beberapa lainnya, memiliki karakteristik yang mirip dengan Sektor Pertambangan dalam hal sifat kegiatan ekstraktif yang mendasarinya. Kenaikan harga minyak dapat meningkatkan permintaan untuk produk-produk ini dan membuat perusahaan pada Sektor Industri Kimia Dasar menjadi lebih menguntungkan. Untuk Sektor Konsumsi juga memiliki korelasi positif dengan Brent karena sektor ini memproduksi barang konsumsi sehari-hari sehingga tingkat kepercayaan konsumen dan permintaan meningkat hal ini yang memungkinkan menjadi alasan dampak positif yang didapat Sektor Konsumsi ketika harga minyak mentah dunia mengalami kenaikan.

Sektor Keuangan memiliki korelasi positif dengan harga minyak dunia, karena tidak menutup kemungkinan perusahaan-perusahaan tambang yang berkaitan erat dengan harga minyak dunia dibiayai oleh sektor ini dapat membayar secara lancar maka dapat mempengaruhi laporan keuangan sektor ini sehingga dapat menarik minat investor. Perubahan harga minyak pada Sektor Keuangan merupakan sebuah risiko pasar. Selanjutnya ada Sektor Infrastruktur, Transportasi dan Utilitas yang juga memiliki korelasi positif hal ini dikarenakan sektor ini wilayah operasionalnya berkaitan erat dengan penggunaan minyak, sudah semestinya setiap subsektor telah mengantisipasi manajemen risiko kenaikan harga minyak dunia, yang dapat 
meningkatkan kepercayaan investor sehingga apabila harga minyak naik dapat meningkatkan nilai harga saham.

Selanjutnya ada sektor pertambangan yang memiliki korelasi positif dengan minyak dunia, hal yang wajar dikarenakan sektor ini sektor yang paling berkaitan dengan minyak. Menurut Pamungkas \& Prasetiono (2018) serta Scholtens \& Yurtsever (2012) industri Minyak, Pertambangan dan Gas akan mendapat keuntungan dari kenaikan harga minyak. Hal tersebut dikarenakan Sektor Pertambangan memproduksi migas, logam, batubara dan lainya yang ketika harga minyak dunia naik maka harga barang tersebut juga naik sehingga laba pada perusahaan Sektor Pertambangan meningkat yang mengakibatkan saham Sektor Pertambangan juga naik. Sektor konsumsi juga memiliki korelasi positif dengan Brent karena sektor ini memproduksi barang konsumsi sehari-hari sehingga tingkat kepercayaan konsumen dan permintaan meningkat hal ini yang memungkinkan menjadi alasan dampak positif yang didapat Sektor Konsumsi ketika harga minyak mentah dunia mengalami kenaikan. Perubahan harga minyak dunia juga memiliki korelasi positif pada Sektor aneka hal ini dimungkinkan terjadi karena manajemen risiko yang diterapkan oleh perusahaan otomotif yang akrab dengan risiko, mampu memperkecil risiko kerugian yang diakibatkan oleh adanya kenaikan harga minyak.

Sektor Properti Real Estate memiliki korelasi yang positif dengan perubahan harga minyak, menurut Suryajaya \& Kurnia (2019) hal ini disebabkan Sektor Properti Real Estate berkorelasi erat dengan daya beli. Ketika permintaan minyak naik maka pertumbuhan ekonomi dan daya beli juga meningkat, hasilnya membuat Sektor Properti Real Estate juga tumbuh yang dapat menarik investor untuk berinvestasi. Sektor Properti Real Estate memiliki korelasi yang lebih kuat dengan WTI dibandingkan yang lain karena WTI lebih menjadi acuan dunia, hal ini memungkinkan bahwa pertumbuhan ekonomi dunia dilihat dari permintaan WTI sehingga secara tidak langsung juga mempengaruhi Sektor Properti Real Estate yang berkaitan dengan daya beli. Yang terakhir adalah Sektor Investasi, Jasa dan Perdagangan yang juga memiliki korelasi positif terhadap perubahan harga minyak mentah dunia. Perusahaan di sektor ini tidak memiliki eksposur yang besar terhadap perubahan harga minyak kecuali subsektor perdagangan besar untuk produksi, yang membuat kenaikan harga minyak merupakan faktor yang memicu kepercayaan investor.

\section{SIMPULAN DAN REKOMENDASI}

Hasil penelitian ini menemukan bahwa ada korelasi positif antara harga minyak dunia (Brent dan WTI) dengan Sektor Pertambangan, Sektor Pertanian, Sektor Industri Kimia Dasar, Sektor Aneka, Sektor Properti Real Estate, Sektor Keuangan, Sektor Infrastruktur, Transportasi dan Utilitas serta Sektor Investasi, Jasa dan Perdagangan, dimana Sektor Pertambangan dan Properti mempunyai korelasi dinamis tertinggi sedangkan ada sektor yang memiliki korelasi negatif yaitu Sektor Industri Barang Konsumsi dengan minyak WTI. Secara keseluruhan korelasi antara pergerakan harga minyak dunia dan Indeks Sektoral adalah lemah. Hal tersebut dikarenakan Pasar Modal di Indonesia tidak hanya fokus perubahan harga minyak, namun juga melihat faktor-faktor lainnya seperti permintaan barang, pertumbuhan ekonomi maupun makro ekonomi. Temuan ini sebagian setuju dengan penelitian sebelumnya, seperti yang dilakukan Arouri (2011); Filis, Degiannakis, \& Floros (2011); Scholtens \& Yurtsever (2012); Trabelsi (2017) diantara lainnya yang juga melaporkan hubungan bervariasi waktu antara perubahan harga minyak dan saham. 
Penelitian ini hanya menggunakan model bivariat, sehingga tidak dapat menangkap variabel eksogen. Penelitian selanjutnya dapat menggunakan model multivariat dengan mempertimbangkan variabel makro ekonomi atau variabel lain yang ada di internal Indonesia, seperti pertumbuhan ekonomi, suku bunga dan lain-lain sebagai variabel eksogen. Panel dinamis GARCH digabungkan dengan DCC juga disarankan untuk penelitian selanjutnya. Bagi para investor atau pedagang dalam pasar saham maupun komoditas, agar dapat mencapai tujuan investasi disarankan dapat menyusun strategi dagang atau portofolio dengan mengikuti dinamika pasar. Bagi investor dan calon investor yang akan melakukan investasi di Indonesia dapat melihat sektor-sektor yang memiliki korelasi positif. Sedangkan Sektor Pertambangan dan Sektor Properti Real Estate dapat dipertimbangkan juga karena memiliki korelasi yang paling tinggi dan dapat menjadi portofolio.

\section{DAFTAR PUSTAKA}

Alghalith, M. (2010). The Interaction Between Food Prices and Oil Prices. Energy Economics, 32(6), 1520-1522.

Alkhateeb, T. T. Y., \& Sultan, Z. A. (2019). Oil price and economic growth: The case of Indian economy. International Journal of Energy Economics and Policy, 9(3), 274-279.

Arouri, M. E. H. (2011). Does Crude Oil Move Stock Markets in Europe? A sector Investigation. Economic Modelling, 28(4), 1716-1725.

Arouri, M. E. H., Lahiani, A., \& Nguyen, D. K. (2015). World gold prices and stock returns in China: Insights for hedging and diversification strategies. Economic Modelling, 44, 273 282.

Basit, A. (2020). Pengaruh Harga Emas dan Minyak Dunia Terhadap Indeks Harga Saham Gabungan (IHSG) Periode 2016-2019. Jurnal Aplikasi Akuntansi, 5(1), 42-51.

Bjørnland, H. C. (2008). Monetary policy and exchange rate interactions in a small open economy. The Scandinavian Journal of Economics, 110(1), 197-221.

Bursa Efek Indonesia. (2010). Buku Panduan Indeks Harga Saham Bursa Efek Indonesia. https://idx.co.id/media/1481/buku-panduan-indeks-2010.pdf

Cermeño, R., \& Grier, K. B. (2001). Modeling GARCH processes in Panel Data: Theory, Simulations and Examples. The University of Oklahoma, Working Paper. https://www.semanticscholar.org/paper/Modeling-GARCH-processes-in-Panel-Data-\%3ATheory-\%2C-Cermeño-Grier/39f13de7087e03eb635f3aaef4792f26fa5a9d78

Engle, R. (2002). Dynamic conditional correlation: A simple class of multivariate generalized autoregressive conditional heteroskedasticity models. Journal of Business and Economic Statistics, 20(3), 339-350.

Filis, G., Degiannakis, S., \& Floros, C. (2011). Dynamic correlation between stock market and oil prices: The case of oil-importing and oil-exporting countries. International Review of Financial Analysis, 20(3), 152-156.

Gumelar, G. (2016). ESDM Pilih Dated Brent Jadi Formula Harga Minyak Baru. Diakses 25 September 2020, https://www.cnnindonesia.com/ekonomi/20160720153618-85145901/esdm-pilih-dated-brent-jadi-formula-harga-minyak-baru

Gumilang, R. C., Hidayat, R. R., \& Endang NP, M. G. W. (2014). Pengaruh Variabel Makro Ekonomi, Harga Emas Dan Harga Minyak Dunia Terhadap Indeks Harga Saham Gabungan. Jurnal Administrasi Bisnis (JAB), 14(2), 1-9. 
Handiani, S. (2014). Pengaruh Harga Emas Dunia, Harga Minyak Dunia dan Nilai Tukar Dolar Amerika/Rupiah Terhadap Indeks Harga Saham Gabungan Pada Periode 2008-2013. EJournal Graduate Unpar, 1(1), 85-93.

Hersugondo, S., Robiyanto, R., Wahyudi, S., \& Muharam, H. (2015). The world oil price movement and stock return in several Southeast Asia's Capital Markets. International Journal of Applied Business and Economic Research, 13(2), 527-534.

Hussin, M. Y. M., Muhammad, F., Razak, A. A., Tha, G. P., \& Marwan, N. (2013). The Link Between Gold Price, Oil Price and Islamic Stock Market: Experience from Malaysia. Journal of Studies in Social Sciences, 4(2), 161-182.

Istamar, Sarfiah, S. N., \& Rusmijati. (2019). Analisis Pengaruh Harga Minyak Dunia, Harga Emas, dan Nilai Kurs Rupiah Terhadap Indeks Harga Saham Gabungan di Bursa Efek Indonesia tahun 1998-2018. DINAMIC: Directory Journal of Economic, 1(4), 433-442.

Jubinski, D., \& Lipton, A. F. (2013). VIX, Gold, Silver, and Oil: How do Commodities React to Financial Market Volatility? Journal of Accounting and Finance, 13(1), 70-88.

Klein, T. (2018). Trends and contagion in WTI and Brent crude oil spot and futures markets The role of OPEC in the last decade. Energy Economics, 75, 636-646.

Le, T.-H., \& Chang, Y. (2011). Dynamics Between Strategic Commodities and Financial Variables. In Economic Growth Centre Working Paper (No. 1104). https://ideas.repec.org/p/nan/wpaper/1104.html

Lin, B., Wesseh, P. K., \& Appiah, M. O. (2013). Oil Price Fluctuation, Volatility Spillover, And The Ghanaian Equity Market: Implication For Portfolio Management And Hedging Effectiveness. Energy Economics, 42, 172-182.

Malkiel, B. G. (2011). The efficient market hypothesis and financial crisis. Working Paper. https://www.russellsage.org/sites/all/files/Rethinking-Finance/Malkiel.

Masih, R., Peters, S., \& Mello, L. D. (2011). Oil price volatility and stock price fluctuations in an emerging market: Evidence from South Korea. Energy Economics, 33(5), 975-986.

Mensi, W. (2019). Global Financial Crisis and Co-movements between Oil Prices and Sector Stock Markets in Saudi Arabia: A VaR based Wavelet. Borsa Istanbul Review, 19(1), 24 38.

Newey, W., \& Mcfadden, D. (1994). Large sample estimation testing. Handbook of Econometrics (Vol. 4, hal. 2113-2245). North-Holland: Elsevier.

Pamungkas P. B. S., \& Prasetiono, P. (2018). Analisis Pengaruh Harga Minyak Dunia, Kurs Rupiah/US\$, dan Fed Rate terhadap Indeks Sektoral Pasar Saham di Indonesia (Periode Januari 2006-Desember 2016). Diponegoro Journal of Management, 7(2), 102-115.

Papiez, M., \& Smiech, S. (2012). Causality in mean and variance between returns of crude oil and metal prices, agricultural prices and financial market prices. 30th International Conference Mathematical Methods in Economics, at Karviná: Silesian Univerity, School of Business Administration, 675-680.

Raraga, F., Chabachib, M., \& Muharam, H. (2012). Analisis Pengaruh Harga Minyak dan Harga Emas Terhadap Hubungan Timbal-Balik Kurs dan Indeks Harga Saham Gabungan (IHSG) Di Bursa Efek Indonesia (BEI) 2000 -2013. Jurnal Bisnis Strategi, 21(1), 72-94.

Ratti, R. A., \& Vespignani, J. L. (2015). OPEC and non-OPEC oil production and the global economy. Energy Economics, 50, 364-378. 
Riga, M. H., Indriana, V., \& Rahmanto, F. (2016). The Effects of Crude Oil Price Changes on the Indonesian Stock Market: A Sector Investigation. Indonesian Capital Market Review, $8(1), 12-22$.

Robiyanto, R. (2017). The Analysis of Capital Market Integration in Asean Region By Using the Ogarch Approach. Jurnal Keuangan dan Perbankan, 21(2), 169-175.

Robiyanto, R., Wahyudi, S., \& Pangestuti, I. R. D. (2017). The volatility-variability hypotheses testing and hedging effectiveness of precious metals for the Indonesian and Malaysian capital markets. Gadjah Mada International Journal of Business, 19(2), 167-192.

Safitri, K. (2020). Harga Minyak Minus, Bagaimana IHSG Hari Ini? Diakses 19 Mei 2020, https://money.kompas.com/read/2020/04/21/081817926/harga-minyak-minus-bagaimanaihsg-hari-ini

Scholtens, B., \& Yurtsever, C. (2012). Oil Price Shocks and European Industries. Energy Economics, 34(4), 1187-1195.

Souček, M. (2013). Crude oil , equity and gold futures open interest co-movements. Energy Economics, 40, 306-315.

Suryajaya, S., \& Kurnia, K. (2019). Pengaruh Nilai Tukar, Harga Minyak, Inflasi Terhadap Delta Properti di Pasar Saham Indonesia. Jurnal Akuntansi Maranatha, 11(1), 146-165.

Suryanto, S. (2017). Pengaruh Harga Minyak Dan Emas Terhadap Indeks Harga Saham Gabungan Di Bursa Efek Indonesia. JURISMA : Jurnal Riset Bisnis \& Manajemen, 7(1), 1 13.

Trabelsi, N. (2017). Tail Dependence Between Oil and Stocks of Major Oil-Exporting Countries Using The CoVaR Approach. Borsa Istanbul Review, 17(4), 228-237.

Tursoy, T., \& Faisal, F. (2018). The impact of gold and crude oil prices on stock market in Turkey: Empirical evidences from ARDL bounds test and combined cointegration. Resources Policy, 55, 49-54. 